\title{
A study to assess the effectiveness of structured teaching programme (STP) on the knowledge among teachers regarding "Identification and management of behavioural problem in children" (IMBP) in a selected primary schools at Dehradun Uttarakhand.
}

\author{
Uma Negi ${ }^{1}$, Sanjenbam Emon Chanu ${ }^{2}$, Shobha Masih ${ }^{3}$
}

\begin{abstract}
Introduction: School children are emerging as creative persons who are preparing for their future role in society. It's the time of new achievement and craze of new experiences in their life. So the parents must understand the normal behavior of the child. Each Child needs and preferences should be respected by their parents. Children spend much time in school as well as at home, therefore teachers and parents are responsible to detect any child which is deviated from the normal behavior and needs concern.

Objectives: The objectives of the study were to evaluate the effectiveness of structured teaching programme on knowledge regarding IMBP in primary school children among teachers and to find out the association between the knowledge score of primary school teachers and selected demographic variable.

Methodology and results: Quasi experimental one group pre-test post-test design was conducted in selected primary schools of Doiwala, Uttarakhand. The study was confined to sixty six primary school teachers who fulfilled inclusion criteria. Pre-test was taken with the help of structured knowledge questionnaire and administered STP on IMBP using posters, PPT and charts. Post test was conducted after 7 days of intervention using same questionnaire. The study shows that in pre test mean knowledge score was 23.9 and in post test it was 38.51 and ' $t$ ' calculated value is 27.58 which is more than the tabulated value of 2.00 at 0.05 level of significance.

Conclusion: The findings of the study revealed that there was significant gain in knowledge score of primary school teachers after STP. So the study concluded that structured teaching programme had a great potential for accelerating the awareness regarding behavioural problems.
\end{abstract}

Key words: Knowledge, Structured teaching programme, Identification and management of behavioural problems.

\section{Introduction}

6-12 years of age is considering as the school age period. School children are emerging as creative persons who are preparing for their future role in society. During the school years the child develops while some attitude toward self as a person and learn the appropriate masculine or feminine social role. The school years are a time of new achievement and experiences in their life so their needs and preferences should be respected. In our country most of the population are children and they are considered as the future of our country, so their safety, basic needs and development is our priority that relies great deal on it is human resource strength. Therefore, it is necessary in the interest of our country to look after the health and welfare as they form the most endangered segment of the population. A better tomorrow depend on the safety, wellbeing and development of children today. So we need to understand proper growth and development of children. Schoolers are emerging as creative function who are preparing for their future role in society and development of society in their own way. Success in schools involves being ever to complete work, stay organized get along with kids and adults, be positive about their abilities and follow rule and doing best work. Before understand children behaviour we should know their needs. In addition to their physical needs for clothing, shelter- children's need fun, freedom, power and a sense of belonging. If these needs aren't fulfilled in positive ways, a problem develops. Every five days of a week, children spend most of their time in school setting. Here they are expected to follow rules, behave in socially acceptable way, participate in academic activities and not disrupt the learning process or activities of others. The work of teacher becomes much more demanding when some learners have attention deficit hyperactivity disorder, as their problem in attention span, impulse control and activity level frequently interfere with activities in the classroom. Children who suffer from behavioural disorders are at a higher risk for school failure, suicide, and mental health problems. The early detection and treatment of children with behavioural problems at an early age may reduce treatment costs and improve quality of life of those children. 
Therefore teachers should be able to identify behavioural and academic problems within first few weeks of a school year.

\section{Objectives}

1. To evaluate the effectiveness of structured teaching programme on knowledge regarding identification and management of behavioural problems in primary school children among teachers.

2. To find the association between the knowledge score of primary school teachers and selected demographic variables.

\section{Hypothesis}

1. $\mathbf{H}_{1}$ : The mean post test knowledge score of teachers will be significantly higher than the mean pre test knowledge score.

2. $\mathbf{H}_{2}$ : There will be a significant association between the knowledge score of teachers with selected demographic variables.

\section{Material And Methods:}

In this present study quasi experimental with one group pre-test, post-test design was adopted as research design to assess the effectiveness of structured teaching programme among primary school teachers regarding identification and management of behavioural problems.

$$
\mathrm{O}_{1} \quad \mathrm{X} \quad \mathrm{O}_{2}
$$

$\mathbf{O}_{1}$ : Assessment of pre-test knowledge regarding identification and management of behavioural problems among primary school teachers before providing structured teaching programme.

$\mathbf{X}$ : Intervention (structured teaching programme on identification and management of behavioural problems).

$\mathbf{O}_{2}$ : Assessment of post-test knowledge regarding identification and management of behavioural problems among primary school teachers.

The present study was conducted in selected four private schools under Doiwala block of Dehradun, Uttarakhand. The study was confined to sixty six primary school teachers who fulfilled inclusion criteria. Pretest was taken with the help of structured knowledge questionnaire and administered STP on IMBP using posters, PPT and charts. Post test was conducted after 7 days of intervention using same questionnaire.

\section{Section A: Socio-demographic characteristics of the participants \\ III. Result}

Table No: 1 Frequency and percentage distribution of the socio-demographic variables $\mathbf{N = 6 6}$

\begin{tabular}{|c|c|c|c|}
\hline S.No & Characteristics & Frequency $(f)$ & Percentage (\%) \\
\hline 1 & $\begin{array}{cr}\text { Age in years } \\
\qquad & 21-33 \\
\bullet & 34-45 \\
\end{array}$ & $\begin{array}{l}51 \\
15 \\
\end{array}$ & $\begin{array}{l}77.3 \\
22.7 \\
\end{array}$ \\
\hline 2 & $\begin{array}{cl}\text { Gender } & \\
\bullet & \text { Male } \\
\bullet & \text { Female } \\
\end{array}$ & $\begin{array}{l}04 \\
62\end{array}$ & $\begin{array}{l}06.06 \\
93.93\end{array}$ \\
\hline 3 & $\begin{array}{cl}\text { Educational status } \\
\bullet \quad \text { Graduation } \\
\text { - } & \text { Post- Graduation }\end{array}$ & $\begin{array}{l}27 \\
39\end{array}$ & $\begin{array}{l}42.42 \\
57.57\end{array}$ \\
\hline 4 & $\begin{array}{l}\text { Years of teaching experience } \\
\text { • } \quad 0-7 \text { years } \\
\text { • } 8-15 \text { years }\end{array}$ & $\begin{array}{l}57 \\
09\end{array}$ & $\begin{array}{l}86.36 \\
13.63\end{array}$ \\
\hline 5 & $\begin{array}{l}\text { Previous knowledge about behavioural problems in } \\
\text { children } \\
\text { - Yes } \\
-\quad \text { No }\end{array}$ & - & - \\
\hline 6 & $\begin{array}{l}\text { Participate in any training program on behavioural } \\
\text { problems in children } \\
\text { - Yes } \\
-\quad \text { No }\end{array}$ & - & - \\
\hline 7 & $\begin{array}{l}\text { In the past have you seen any children with } \\
\text { behavioural problems in your school } \\
\text { - Yes } \\
\text { - No }\end{array}$ & - & - \\
\hline
\end{tabular}


The data presented in Table No: 1 revealed that the most of primary school teachers $(77.33 \%)$ were within the age group of 21-33 years. Most of teachers (93.09\%) were females. Less than half of primary school teachers $(42.42 \%)$ were graduate. Majority of school teachers $(86.36 \%)$ had 1-7 years of teaching experience. All primary school teachers had no previous knowledge about behavioural problems in children. They had never participated in any training programme on behavioural problems in children and teachers had never seen any child with behavioural problem.

\section{Section B: Effectiveness of structured teaching programme on IMBP}

$\mathbf{H}_{\mathbf{0}}$ : There would be no difference between pre-test knowledge score and post test knowledge score.

$\mathbf{H}_{1}$ : The mean post test knowledge score of teachers would be significantly higher than the mean pre test knowledge score.

Table No: 2 Comparisons of pre-test and post-test knowledge scores of participants. N=66

\begin{tabular}{|c|l|l|l|l|l|}
\hline S. No & Knowledge score & Mean \pm SD & Mean Difference & 't' value & P Value \\
\hline $\mathbf{1}$ & Pre-test & $23.98 \pm 4.74$ & & & \\
\hline $\mathbf{2}$ & Post -test & $38.51 \pm 2.96$ & 14.53 & $27.58^{*}$ & 0.001 \\
\hline
\end{tabular}

df $=65$ (tab. value is 2.00 at $p<0.05)$

The data presented in table No: 2 showed that the mean post test knowledge scores were apparently higher than the pre test knowledge scores and obtained ' $t$ ' value was 27.58, with $p$ value 0.001 . Mean pre-test and post-test knowledge score were computed and found 23.98 and 38.51 respectively which was significantly higher than that of their mean pre-test score. Hence the score predicts that the significant difference between the mean of pre-test and post-test at $\mathrm{p}<0.05$ level. So there was no evidence to accept the null hypothesis, hence the researcher rejected the null hypothesis and alternative research hypothesis was accepted indicating the gain in knowledge was not by chance but because of the intervention.

Table No: 3 Area wise comparisons of pre-test post test knowledge score of participants N=66

\begin{tabular}{|c|c|c|c|c|c|c|c|}
\hline \multirow[t]{2}{*}{ S.N } & \multirow{2}{*}{$\begin{array}{c}\text { Area of } \\
\text { knowledge }\end{array}$} & \multicolumn{2}{|c|}{ Pre-test } & \multicolumn{2}{|c|}{ Post-test } & \multirow[t]{2}{*}{ 't' value } & \multirow[t]{2}{*}{$P$ value } \\
\hline & & Mean & SD & Mean & SD & & \\
\hline 1 & Temper tantrum & 4.56 & 1.20 & 6.42 & 1.19 & $8.81 *$ & 0.0001 \\
\hline 2. & Tics & 3.38 & 1.61 & 6.07 & 1.39 & $10.72 *$ & 0.0001 \\
\hline 3. & School phobia & 4.01 & 1.44 & 6.68 & 1.02 & $12.99 *$ & 0.0001 \\
\hline 4. & ADHD & 4.54 & 1.51 & 6.32 & 0.98 & $8.50 *$ & 0.0001 \\
\hline 5. & Pica & 4.61 & 1.85 & 7.02 & 1.19 & $9.53 *$ & 0.0001 \\
\hline 6. & Conduct disorder & 2.95 & 1.50 & 5.28 & 1.22 & $9.97 *$ & 0.0001 \\
\hline
\end{tabular}

' $\mathrm{t}$ ' $65=2.00, \mathrm{p}<0.05$. *indicates significant

The data presented in table No.3 shows that the mean post test knowledge scores in all areas of behavioural problems were higher than the mean pre-test knowledge scores. This indicates that knowledge of primary school teachers with behavioural problems improved after structured teaching programme.

Figure No: 3 Bar diagram illustrates the comparison of mean percentage of pre-test and post-test knowledge score according to area wise knowledge.

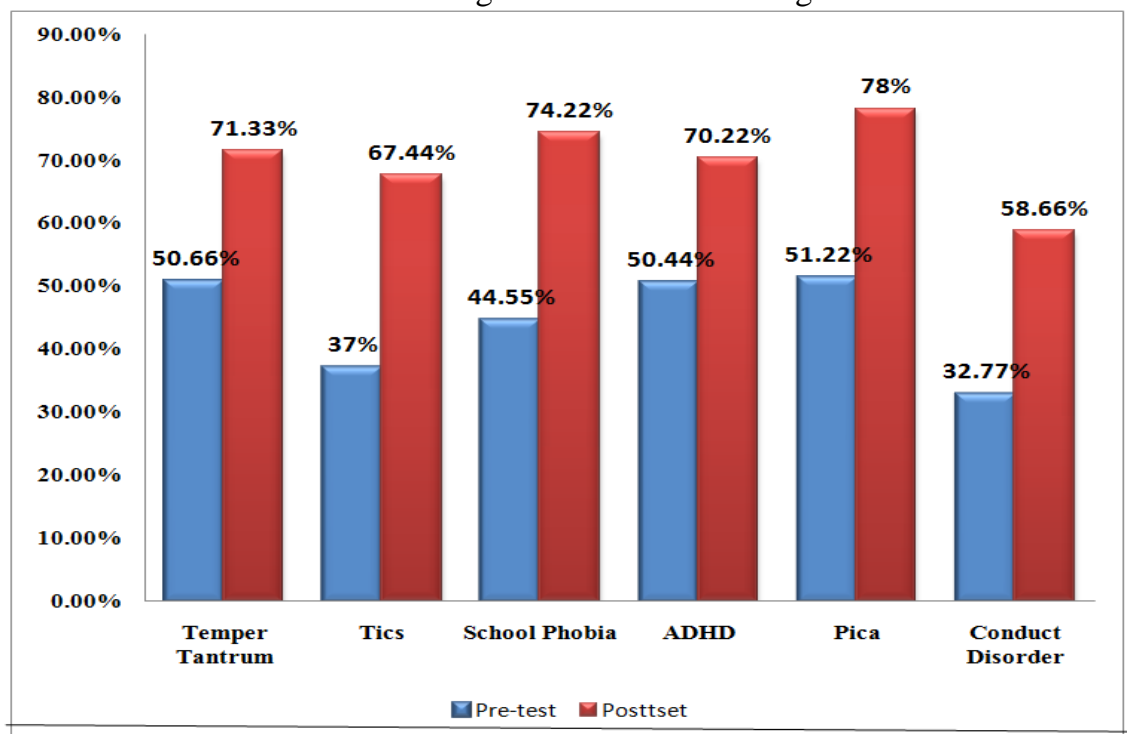


Figure No: 3 shows that the highest mean pre-test mean score was in the area of Pica $(51.22 \%)$ and lowest was in conduct disorder $(32.77 \%)$. The highest post test mean percentage was 7.02 in the knowledge area of Pica and lowest post test was in the area of (78\%) conduct disorder (58.66\%). Highest effectiveness in the area of tics and school phobia (67.44 and 74.22\%) and lowest effectiveness in the area of ADHD (70.22\%). Apparently all areas of mean post test score were higher than that of their pre-test knowledge score. Hence it shows that structured teaching programme regarding IMBP was effective in all areas.

Section C: Association between pre-test knowledge score socio demographic variables and of participants. $\mathbf{H}_{0}$ : There would be no significant association between pre-test knowledge score of participants with their selected socio demographic variables.

$\mathbf{H}_{2}$ : There would be a significant association between the knowledge score of teachers with selected demographic variables.

Table No: 4 Association of pre-test knowledge scores with selected socio-demographic variables.

\begin{tabular}{|c|c|c|c|c|c|}
\hline S.No & Characteristics & $<$ Median (24) & At and above median (24) & $x^{2}$ & P value \\
\hline 1 & $\begin{array}{l}\text { Age in years } \\
\bullet \quad 21-33 \\
\bullet \quad 34-45\end{array}$ & $\begin{array}{l}15 \\
05\end{array}$ & $\begin{array}{l}36 \\
08\end{array}$ & 1.505 & 0.21 \\
\hline 2 & $\begin{array}{ll}\text { Gender } \\
-\quad \text { Male } \\
\text { - Female } \\
\end{array}$ & $\begin{array}{l}02 \\
25 \\
\end{array}$ & $\begin{array}{l}01 \\
38 \\
\end{array}$ & 0.506 & 0.45 \\
\hline 3 & $\begin{array}{cl}\text { Educational qualification } \\
- & \text { Graduation } \\
\bullet & \text { Postgraduation }\end{array}$ & $\begin{array}{l}13 \\
14\end{array}$ & $\begin{array}{l}14 \\
25\end{array}$ & 0.504 & 0.31 \\
\hline 4 & $\begin{array}{l}\text { Years of teaching } \\
\text { experience } \\
\text { - } \quad 0-7 \text { years } \\
\text { - } \quad 8-15 \text { years }\end{array}$ & $\begin{array}{l}24 \\
03\end{array}$ & $\begin{array}{l}33 \\
06\end{array}$ & 0.018 & 0.89 \\
\hline
\end{tabular}

df $(1)=3.84$ at $\mathrm{p}<0.05$

The above table no: 4 depicts that since chi square value for age $\left(X^{2}=1.504, \mathrm{p}>0.05\right)$, gender $\left(X^{2}=\right.$ $0.506, \mathrm{P}>0.05)$, educational qualification $\left(X^{2}=0.504, \mathrm{P}>0.05\right)$, years of teaching experiences $\left(X^{2}=0.018, \mathrm{P}>0.05\right)$ the research hypothesis is rejected. So there is no significant association between knowledge of primary school teachers and age, gender, educational qualification, teaching experiences.

\section{Discussion:}

The main purpose of the study was to assess the effectiveness of structured teaching programme on identification and management of behavioural problems in selected primary schools of Doiwala Uttarakhand. The total 66 primary school teachers were selected through convenient sampling technique. Pre-test was conducted by using structured questionnaire. Structured teaching programme was given by investigator. After seven days post-test was conducted by using same questionnaire. The structured teaching programme was given regarding identification and management of behavioural problems. After intervention knowledge score was increased in post test.

The present study showed that there was improvement in knowledge of school teachers.

The study findings was supported by a study conducted by Shubhangi S. Dumbray, Shubhada Kale, Arpana jadhav, Neetu P.V(2014) on effectiveness of structured teaching programme on knowledge of mothers regarding behavioural problems of children, one group pre test post-test design was used ,study done in Pune India. Findings of the study revealed that, in pre-test, majority i.e. $86.7 \%$ of the subjects had poor knowledge (Score $0-8$ ) and $13.3 \%$ of them had average knowledge (Score 9-16). In post-test, majority i.e. $71.7 \%$ of them had good knowledge (Score 17-25) and $28.3 \%$ of them had average knowledge (Score 9-16).The study concludes that there is significant difference in the pre-test and post-test knowledge scores mean; this indicates that the structured teaching program is effective in improving the knowledge of subjects.

This study finding was supported by a study conducted by Gurdeep kaur, Dr. Sushant Kumar Pradhan (2013), on awareness among teachers with regards to the school student's behavioural problem in selected schools of Kurushetra city of Haryana. This study indicates that the planned teaching is effective in increasing the knowledge of teachers regarding behavioural problem. Another study finding was also supported by a study conducted by Prashant B Patil( 2013), on Effectiveness of Structured Teaching Programme on Knowledge and Attitude of Primary School Teachers Regarding Attention Deficit Hyperactivity Disorder Karnataka India. The result showed the significant difference suggesting that the STP was effective in increasing the knowledge and attitude of the teachers $(t=14.34, t=7.57)$. The mean post-test knowledge and attitude scores $\left(X_{2}=43.17, X_{2}=\right.$ 
52.72) higher than the mean pre-test knowledge and attitude scores $\left(X_{1}=30.40, X_{1}=44.52\right)$. There was a significant positive correlation between knowledge and attitude $r=0.227$ at 0.05 level of significance. Hence the structured teaching programme is an effective strategy for providing information and improving the knowledge of subjects.

The present study showed that there was no significant association between pre-test knowledge of primary school teachers with their socio- demographic variables:

This study finding was supported by Sandeep Garg, Arpan Pandya, Ravindra N.N. (2014) on Common Behavioural Problems of primary school teachers of Vadodara-Gujarat, India. The study shows that in pre- test mean score was $14.82 \pm 3.372$ and in post test mean score was $22.75 \pm 2.802$ and there was no association in knowledge of teachers with age in years $(\mathrm{p}=0.33)$, educational qualification $(\mathrm{p}=0.50)$, years of teaching experience(0.96).

Another study findings was also supported by Manoj Kumar Jangir.(2012), on effectiveness of an instructional module regarding behavioral assessment of children on the knowledge and self practices of teachers, one group pre-test post test design was used, study done in Dehradun Uttarakhand. The study findings showed that there was no significant association between pre-test knowledge score of primary school teachers with their socio-demographic variables such as age $\left(X^{2}=0.53, p>0.05\right)$, educational status $\left(X^{2}=0.008, p>0.05\right)$, teaching experiences $\left(X^{2}=0.24, \mathrm{P}>0.05\right.$, ever met with child with behavioral problem $\left(X^{2}=0.11, \mathrm{P}>0.05\right)$ and attend any awareness programme related to behavioral problem $(X 2=0.64, \mathrm{p}>0.05)$.

\section{Recommendations}

- Allocation of more time and resources to intervention like school visits by mental health professional and workshops to positivity influence attitude and practices of teachers.

- A practical and useful course in child and adolescent mental health need be a part of the curriculum of teacher's colleges and focus of in-service education.

- A similar study may be replicated on a larger sample.

- A descriptive study can be conducted to assess the knowledge of parents on identification and management of behavioural problems.

Limitation

- Study samples are predominantly females and almost all subjects are from private schools so hence the generalization of the findings is limited.

- The study was confined with small Sample size and no control group.

\section{Conclusion}

- The findings of the study revealed that there was significant gain in knowledge score of primary school teachers after STP. So the study concluded that structured teaching programme had a great potential for accelerating the awareness regarding behavioural problems.

\section{References:}

[1] Centre for community child health. 2006. Behaviour problems. Practice resource.p-8

[2] Dorthy.R.Marlow, Barbara.A. Redding, Textbook of Paediatric Nursing. $6^{\text {th }}$ edition. New Delhi publications: W.B.Saunders company; 2008 page no1012-13.

[3] https://www.betterhealth.vic.gov.au/health/healthyliving/behavioural-disorders-in-children.

[4] www.greatschools.org/gk/articles/helping-change-behavior.changingchildren's behavior in school. 2015.

[5] http://acbray.wordpress.com. Children are like wet cement, whatever of falls on them make an impression. 2015.

[6] Dutta Parul. Paediatric Nursing, $2^{\text {nd }}$ edition, Jaypee publication, p 186.

[7] http://eassay.pw/essay/structured teaching programme onBehavioural problems. education essay.

[8] https://studentaid.ed.gov/sa/repay-loans/forgiveness-cancellation/teacher https://books.google.co.in/books?id=URM7AAAAIAAJ. The Code of Federal Regulations of the United States of America.

[9] www.pearweb.org. student-teacher relationship. Bridget. K. Hamre, Robert C.Painte.

[10] http://www.communicationskillsworld.com/communicationskillsforteachers.html. Communication Skill for Teachers

[11] www.rguhs.ac.in/cdc/onlinecdc/uploads/05. Attention deficit hyperactivity disorder.

[12] Sarita Bhargava, O.P.Garg, Dr. Sumit Singh, Pratibha Singh. Prevalence of behaviour problems in Ajmer school children. The Indian journal of paediatrics.2014. Volume 55.p408-15

[13] www.rguhs.ac.in/cdc/onlinecdc/uploads/05_N134_12321.com.Teacherscomplete knowledge of attention deficit.

[14] https://www.teachervision.com/teaching-methods/classroom-management/7236. Effective behaviour manager-Teachersvision.com. 